\title{
Delineation of Groundwater Potential using Electrical Resistivity Method at Gidan Madara Mubi - South, Adamawa State, North-Eastern Nigeria
}

\author{
Lazarus G.N \\ Department of Pure and Applied Physics, \\ Adamawa State University Mubi, Adamawa State, \\ Nigeria.
}

\author{
Abdul-Lateef U \\ Department of Science Laboratory Technology, \\ Federal Polytechnic Mubi, Adamawa State, \\ Nigeria.
}

\author{
Sunday A \\ Department of Science Laboratory Technology, \\ Federal Polytechnic Mubi. Adamawa State, \\ Nigeria.
}

\begin{abstract}
Delineation of groundwater potential using electrical resistivity method at Gidan Madara was carried out to determine the groundwater potential zones and depth, the lithology of the area and possible best site for drilling boreholes. Ten VES points were sounded in the study area with the ABEM SAS 1000 Terrameter. Schlumberger array was used during the acquisition of data with maximum electrode spacing of $100 \mathrm{~m}$. Data obtained were interpreted both qualitatively and quantitatively. The following VES points; VES 1,2,6,7,8, 9 and 10, were found to have good potential for ground water exploration due to the presence of fracture/weathered zone of low resistivity. Depth to this zones ranges from $40 \mathrm{~m}$ to $70 \mathrm{~m}$ while VES points 3,4 and 5 do not possess groundwater potentials because they were of high resistivity values.
\end{abstract}

\section{INTRODUCTION}

Water is essential for development of different season's irrigation, industry and domestic purpose. Groundwater is the main source for portable water supply, domestic, industrial and agricultural uses. The scarcity of groundwater increases day by day due to rapid population, urbanization, industrial and agricultural related activities. Groundwater is more advantageous than the surface water due to its lesser extent of evaporation. Water scarcity problem affects the human chain and other living things. The rapid rural development in and around the study area and the associated activities have resulted in the increase of population demands leading to excesses utilization of groundwater. Geophysics has played a useful role for groundwater exploration for many years and improvements in instruments and the development of better methods is resulting in a widening of its applications. It is used to measure the physical properties of the subsurface, specifically related to the position of water and its quality, and the position and properties of geological units. Consequently, the geo-electrical resistivity and electromagnetic geophysical prospecting methods are increasingly being used in addressing a wide variety of mineral exploration, hydrogeological, environmental and geotechnical problems by determining the spatial and/or temporal variability of subsurface electrical properties (resistivity/conductivity and dielectric constant) (Aizebeokhai and Oyeyemi, 2014). The electrical resistivity method primarily allows measurement of the potential differences on the surface due to the current flow within the ground. This method employs a phenomenon which makes possible the delineation and fluid content determination of various subsurface geologic units by the analysis of their electrical resistance response. Since there exists a close relationship between the electrical conductivity and some hydrogeological properties of an aquifer system, the electrical resisitivity method has widely been used for quantitative estimation of water transmitting properties of aquifers, aquifer zone delineation and evaluation of the geophysical properties of the aquifer zone in several locations (De Lima and Niwas 2000; Chandra et al., 2004; Louis et al., 2004; Mufid Al-Hadithi et al., 2006; Niwas and de Lima 2003; Dhakate and Singh 2005; Khalil, 2006). This work is aim at using the electrical resistivity technique to delineate the subsurface lithology an assessment of groundwater potential of the area under study.

\section{STUDY AREA}

The area lies within Latitude $10^{\circ} 015^{\prime} \mathrm{N}$ and $10^{\circ} 025^{\prime} \mathrm{N}$ and Longitude $13^{\circ} 015^{\prime} \mathrm{E}$ and $13^{\circ} 025^{\prime} \mathrm{E}$. The area is about $10 \mathrm{~km}^{2}$ and is quite accessible. The topography of the area is typically of steep hills, undulating slopes and gentle escarpment. The landform is the consequence of geological and geomorphological processes. The area is characterized by high relief ranging from $2000 \mathrm{~m}$ above sea level in the western part to $3900 \mathrm{~m}$ above sea level in the southern part of the area.

The study area is covered by hard rock formations, and faces acute water scarcity problem both with respect to irrigation as well as drinking purposes. Occurrence of groundwater in this type of area is limited to fractured and weathered horizons and upper unconsolidated materials. 


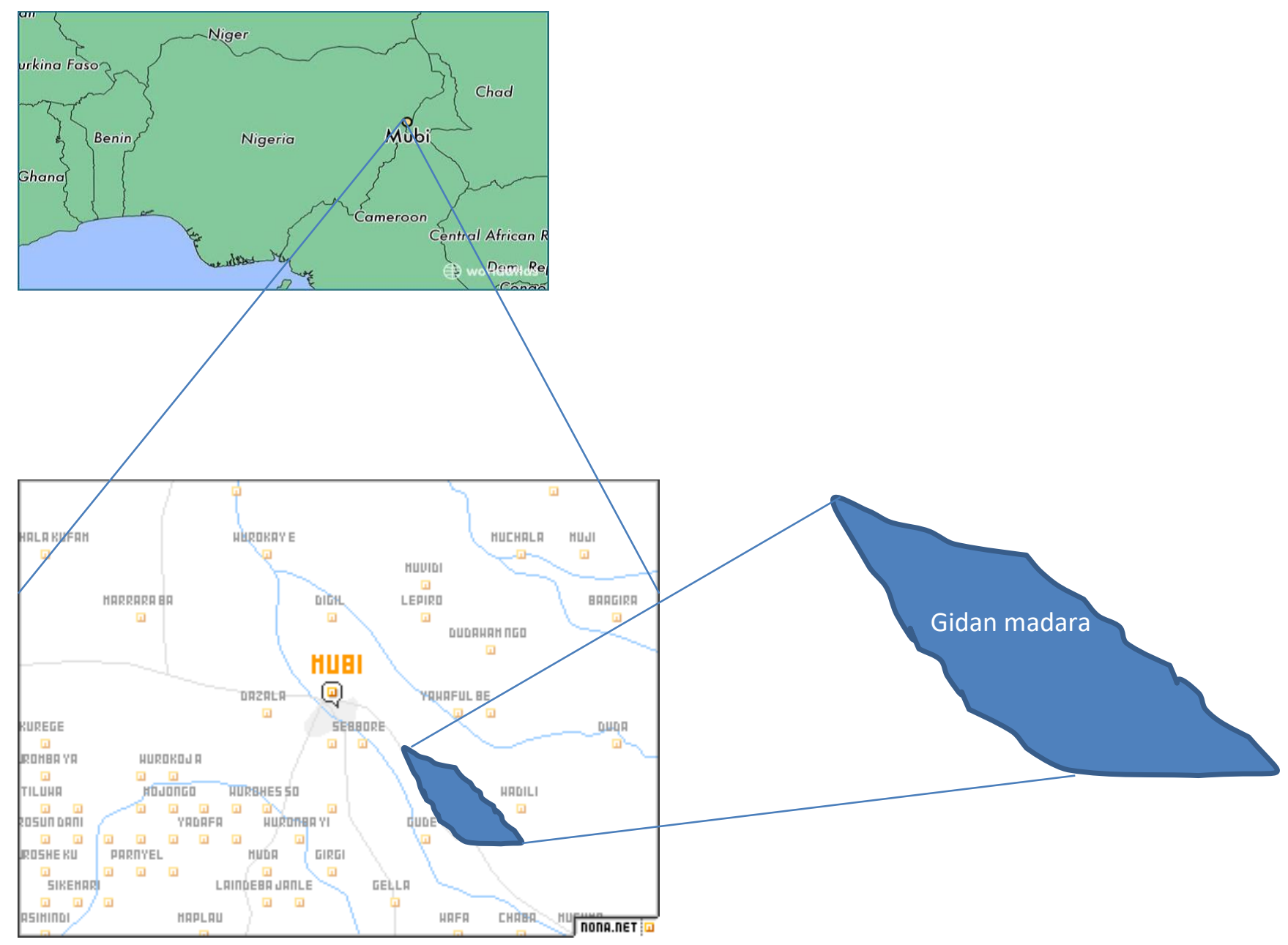

Fig. 1: Location map of the study area

\section{GEOLOGY OF THE STUDY AREA}

The study area is located within the Precambrian Basement Complex in the Northern Part of Adamawa State. These consist of conglomerates with interbedded sandstones. In some places however, lateritic soils overly the basement complex rocks. The recent river cause alluvium is confined to the flood plains of the Yadsaram River and its tributaries. It is characterized by fine- medium grained sandy materials with clay pebbles of the surrounding basement rocks. The basement complex rocks underlying the study area are referred to as the undifferentiated basement rocks. These include Older Granites, Migmatites and Gneiss. The Older Granite series include rocks intruded during the Pan African Orogenic cycle. These rocks are divided into three (3) main groups, basic and intermediate intrusive, migmatite and syntectonic to late tectonic Granite (McCurry, 1976).

\section{MATERIALS AND METHODS}

The geophysical instruments used in this study include the following: ABEM SAS1000 Terameter, electrodes (current electrodes and potential electrode), reels of connecting cables, battery and hammer. A total of 10 VES points were occupied on the study area with maximum electrode spacing of $100 \mathrm{~m}$. The Vertical Electrical Sounding which is a 1-D resistivity approach is used to measure the vertical variations in electrical properties beneath the earth surface using the Schlumberger electrode configuration. It involves the use of a pair of current electrodes and a pair of potential electrodes to measure the resultant potential difference within the subsurface (Fig. 2). Data are obtained by increasing the electrode spacing linearly about a central position whose vertical resistivity variation is sought. 


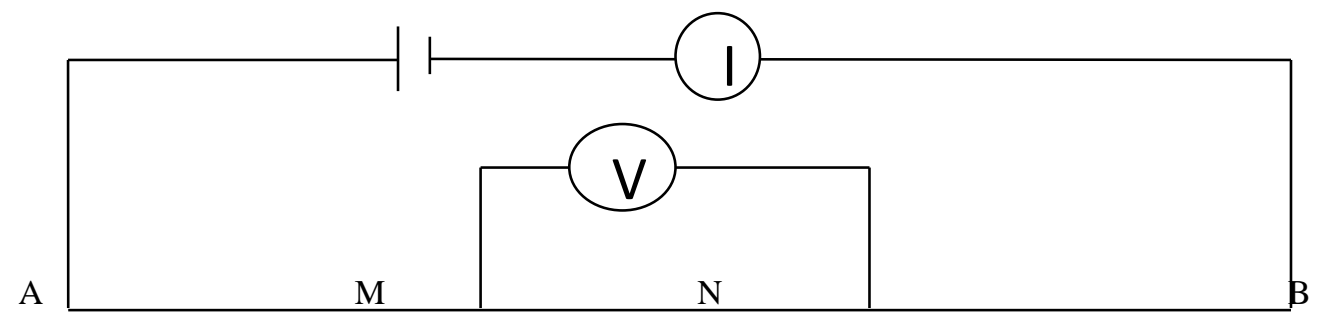

Fig. 2: Schlumberger Configuration.

Resistance measurements are made at each expansion and multiplied by the respective geometric factor (K) to give the apparent resistivity of the point using the equation;

$$
\rho_{a}=\frac{K V}{I}=K R
$$

Where

$$
K=\frac{\frac{\Pi}{2}\left[\left(\frac{A B}{2}\right)^{2}-\left(\frac{M N}{2}\right)^{2}\right]}{\left(\frac{M N}{2}\right)}
$$

$\rho_{a}$ is apparent Resistivity, $\mathrm{K}$ is Geometric Factor, V is Voltage, $\mathrm{I}$ is Current, $\mathrm{R}$ is Resistance, AB is the Current Electrode Separation and $\mathrm{MN}$ is potential electrode separation.

During data acquisition the electrodes were connected appropriately to their respective terminals on the Terameter through cables and hammered to make good contact with the earth. During the sounding, the instrument sends down direct current into the earth subsurface through the pair of steel current electrodes, while the established subsurface potential difference across the subsurface under investigation was measured by the Terameter through the steel potential electrodes. For each sounding, the Terameter computes and displays a mean digital value of the apparent resistivity of the subsurface under investigation.

\section{RESULT}

The apparent resistivity data were processed by Interpex IX1D resistivity software using one dimensional (1D) inversion to model the vertical variations of subsurface resistivity at different depths. This software allows the user to enter apparent resistivity data in a standard geo-soft format. It also smoothens the field curve through the process of filtering technique that involves single point correction and vertical curve segment shift. This package is capable of converting the values of apparent resistivity as function of electrode spacing acquired as the field data to values of true resistivity as function of depth of individual layer for the actual condition in the ground to be interpreted. The result of the interpreted data is presented in Table 1.

\begin{tabular}{|c|c|c|c|c|c|}
\hline VES No. & No. of Layers & $\rho_{a}$ (ohm-m) & Thickness & Depth & Lithology \\
\hline \multirow[t]{3}{*}{1} & 1 & 160 & 4.2 & & Top soil \\
\hline & 2 & 70 & 10 & 4.2 & Weathered basement \\
\hline & 3 & 30700 & & 14.2 & Fresh basement \\
\hline \multirow[t]{3}{*}{2} & 1 & 180 & 3.4 & & Top soil \\
\hline & 2 & 8 & 10 & 3.4 & Weathered basement \\
\hline & 3 & 90000 & - & 13.4 & Fresh basement \\
\hline \multirow[t]{3}{*}{3} & 1 & 2500 & 4.7 & & Top soil/moist \\
\hline & 2 & 2.0 & 5 & 4.7 & Weathered basement \\
\hline & 3 & 150000 & & 9.7 & Fresh basement \\
\hline \multirow[t]{3}{*}{4} & 1 & 16000 & 2.0 & & Top soil \\
\hline & 2 & 3000 & 2.0 & 2.0 & Alluvium \\
\hline & 3 & 0.8 & & 4.0 & weathered basement \\
\hline \multirow[t]{2}{*}{5} & 1 & 48000 & 0.9 & & Top soil \\
\hline & 2 & 2700 & 3 & 0.9 & Alluvium/overburden \\
\hline
\end{tabular}

Table 1: Number of layer apparent resistivity, thickness, depth and lithology for VES 


\begin{tabular}{|c|c|c|c|c|c|}
\hline & 3 & 2300 & & 3.9 & weathered basement \\
\hline \multirow[t]{3}{*}{6} & 1 & 180 & 1.3 & & Top soil \\
\hline & 2 & 2.5 & 4 & 1.3 & Weathered basement \\
\hline & 3 & 460 & & 5.3 & Fresh basement \\
\hline \multirow[t]{3}{*}{7} & 1 & 70 & 6.3 & & Top soil \\
\hline & 2 & 12 & 5 & 6.3 & Weathered basement \\
\hline & 3 & 13000 & & 11.3 & Fresh basement \\
\hline \multirow[t]{3}{*}{8} & 1 & 180 & 1.8 & & Top soil \\
\hline & 2 & 4 & 6 & 1.8 & Weathered basement \\
\hline & 3 & 14000 & & 7.8 & Fresh basement \\
\hline \multirow[t]{3}{*}{9} & 1 & 500 & 0.9 & & Top soil \\
\hline & 2 & 12 & 15.1 & 0.9 & Alluvium/overburden \\
\hline & 3 & 100000 & & 16 & Fresh basement \\
\hline \multirow[t]{3}{*}{10} & 1 & 70 & 6.2 & & Top soil \\
\hline & 2 & 0.8 & 3 & 6.2 & Weathered basement \\
\hline & 3 & 15000 & & 9.2 & Fresh basement \\
\hline
\end{tabular}

\section{DISCUSSION OF RESULT}

The geoelectric section of VES 1 indicates three geoelectric layers and its apparent resistivity. The curve is the H-type, with $\rho_{1}>\rho_{2}<\rho_{3}$. The first layer has a resistivity value of $160 \Omega \mathrm{m}$ with a thickness of $4.2 \mathrm{~m}$ in top soil. The second layer has a resistivity value of $70 \Omega \mathrm{m}$ with thickness of $10 \mathrm{~m}$ at weathered basement, the third layer resistivity is $30,700 \Omega \mathrm{m}$ and it is suspected to be fresh basement.

The geoelectric section of VES 2 indicates three geoelectric layers and its apparent resistivity. The curve is the H-type, with $\rho_{1}>\rho_{2}<\rho_{3}$. The first layer has a resistivity value of $180 \Omega \mathrm{m}$ with thickness of $3.4 \mathrm{~m}$ in top soil. The second layer has a resistivity value of $8.0 \Omega \mathrm{m}$ with thickness of $10 \mathrm{~m}$ still at the top soil. The third layer has a resistivity value of $90,000 \Omega m$ and it is suspected to be fresh basement.

The geoelectric section of VES 3 indicates three geoelectric layers and its apparent resistivity curve is the A-Types, with $\rho_{1}>\rho_{2}<\rho_{3}$. The first layer has a resistivity value of $2500 \Omega \mathrm{m}$ with thickness of $4.7 \mathrm{~m}$ in top soil $/$ moist. The second layer has a resistivity value of $2.0 \Omega \mathrm{m}$ with thickness of $5 \mathrm{~m}$ at weathered basement. The third layer has resistivity of $150,000 \Omega \mathrm{m}$ and it is suspected to be fresh basement.

The geoelectric section of VES 4 indicate three geoelectric layers and its apparent resistivity curve is the Q-type, with $\rho_{1}>\rho_{2}>\rho_{3}$. The first layer has a resistivity value of $16,000 \Omega \mathrm{m}$ with thickness of $2.0 \mathrm{~m}$ top soil. The second layer has a resistivity of $3,000 \Omega \mathrm{m}$ with thickness of $2 \mathrm{~m}$ at the Alluvium and the third layer has $0.8 \Omega \mathrm{m}$ and it is suspected to be weathered basement.

The geoelectric section of VES 5 indicates three geoelectric layers and it is apparent resistivity curve is the Q-type, with $\rho_{1}>\rho_{2}>\rho_{3}$. The first layer has a resistivity value of
$48,000 \Omega \mathrm{m}$ with thickness of $0.9 \mathrm{~m}$ at the top soil. The second layer has a resistivity value of $2,700 \Omega \mathrm{m}$ with thickness of $3 \mathrm{~m}$ at Alluvium/Overburden. The third layer has resistivity of $2,300 \Omega \mathrm{m}$ it is suspected to be weathered basement.

The geoelectric section of VES 6 indicates three geoelectric layers and it is apparent resistivity curve is the H-Type, with $\rho_{1}>\rho_{2}<\rho_{3}$. The first layer has a resistivity value of $180 \Omega \mathrm{m}$ with thickness of $1.3 \mathrm{~m}$ at the top soil. The second layer has resistivity value of $2.5 \Omega \mathrm{m}$ with thickness of $4 \mathrm{~m}$ at weathered basement. The third layer has resistivity of $460 \Omega \mathrm{m}$ and it is suspected to be fresh basement.

The geoelectric section of VES 7 indicates three geoelectric layers and it is apparent resistivity curve is the H-Type, with $\rho_{1}>\rho_{2}<\rho_{3}$. The first layer has a resistivity value of $70 \Omega \mathrm{m}$ with thickness of $6.3 \mathrm{~m}$ at the top soil. The second layer has resistivity value of $12 \Omega \mathrm{m}$ with thickness of $5 \mathrm{~m}$ at weathered basement. The third layer has resistivity of $13,000 \Omega \mathrm{m}$ and it is suspected to be fresh basement.

The geoelectric section of VES 8 indicates three geoelectric layers. It's apparent resistivity curve is the H-Type, with $\rho_{1}$ $>\rho_{2}<\rho_{3}$. The first layer has a resistivity value of $180 \Omega \mathrm{m}$ with thickness of $1.8 \mathrm{~m}$ at the top soil. The second layer has resistivity value of $4 \Omega \mathrm{m}$ with thickness of $6 \mathrm{~m}$ as a fractured basement. The third layer has resistivity of $14,000 \Omega m$ with and it is suspected to be fresh basement.

The geoelectric section of VES 9 indicates three geoelectric layers. It's apparent resistivity curve is the H-type, with $\rho_{1}$ $>\rho_{2}<\rho_{3}$. The first layer has a resistivity value of $500 \Omega m$ with thickness of $0.9 \mathrm{~m}$ at the top soil. The second layer has resistivity value of $12 \Omega \mathrm{m}$ with thickness of $15.1 \mathrm{~m}$ at the Alluvium/Overburden. The third layer has resistivity of $>100,000 \Omega \mathrm{m}$ and it is suspected to be fresh basement. 
The geoelectric section of VES 10 indicates three geoelectric layers. It's apparent resistivity curve is the $\mathrm{H}$ Type, with $\rho_{1}>\rho_{2}<\rho_{3}$. The first layer has a resistivity value of $70 \Omega \mathrm{m}$ with thickness of $6.2 \mathrm{~m}$ at the top soil. The second layer has resistivity value of $0.8 \Omega \mathrm{m}$ with thickness of $3 \mathrm{~m}$ at the weathered basement and the third layer has resistivity of $15,000 \Omega \mathrm{m}$ and it is suspected to be fresh basement.

\section{CONCLUSION}

Delineation of groundwater potential using electrical resistivity method at Gidan Madara, Mubi South to determine the depth and the geo-electric units. Vertical Electrical Sounding (VES) method using Schlumberger array has proved to be effective. Analysis of the interpreted result has shown the nature and sub-surface lithology unit. Thus, this includes the top soil, Alluvium, weathered basement, Fractured and Fresh basement. Base on the resistivity values of the area, the potential zones for groundwater exploration has been identified at VES $1,2,6,7,8,9$ and 10 because of their low resistivity values, while VES 3,4 and 5 do not possess groundwater potentials because of high resistivity values.

\section{REFERENCES}

[1] Aizebeokhai PA, Oyeyemi KD (2014).Application of geoelectrical resistivity imaging and VLF-EM for subsurface characterization in a sedimentary terrain, Southwestern Nigeria. Arab J Geosci

[2] Chandra S, Ch R, Rao VA, Singh VS, Jain SC (2004).Estimation of natural recharge and its dependency on sub-surface geoelectric parameters. J Hydrol. doi:10.1016/j.jhydrol.2004.04.001

[3] De Lima OAL, Niwas S (2000).Estimation of hydraulic parameters of shaly sandstone aquifers from geological measurements. J Hydrol 235:12-26

[4] Dhakate R, Singh VS (2005). Estimation of hydraulic parameters from surface geophysical methods, Kaliapani Ultramafic Complex, Orissa, India. J Environ Hydrol 13(12):1-11

[5] Khalil MH (2006). Geoelectric resistivity sounding for delineating salt water intrusion in the Abu Zanima area, west Sinai, Egypt. J Geophys Eng 3:243-251

[6] Louis I, Karantonis G, Voulgaris N, and Lois F (2004).Geophysical methods in the determination of aquifer parameters: the case of Mornos river delta, Greece. Res J Chem Environ 18(4):41-49

[7] McCurry, P (1976). The geology of the Precambrian to Lower Paleozoic rocks of Northern Nigeria, a review in Geology of Nigeria (CA Kogbe ed) Elizabethan Pub Coy Lagos

[8] 15-39

[9] Mufid Al-Hadithi DC, Israil M and Kumar B (2006). Groundwaterrecharge estimation using a surface electrical resistivity method in the Himalayan foothill region, India. Hydrogeol J (14):44-50.

[10] Niwas S, and de Lima OAL (2003). Aquifer parameter estimation from surface resistivity data. Groundwater 41(1):94-99 